Претходно саопштење

Издање научне грађе https://doi.org/10.18485/folk.2020.5.2.8 392.4:[001.891.7+801.3](497.5 Drežnica)"20" 392.4:[001.891.7+801.3](497.113 Bajmok)"20"

\title{
Мачкаре из Дрежнице
}

\author{
Бранко Ћупурдија
}

Предмет рада су мачкаре у српским селима Дрежнице, на тромеђи Горског Котара, Хрватског приморја и Лике. Истраживање почива на петнаест усмених и једном писаном исказу и литератури. Грађа је сакупљена у периоду од 2000. до 2013. године у Дрежници и Бајмоку, где је од 1945. до 1948. године пресељена око једна трећина становника Дрежнице, и 2018. године у Београду. Истраживање је показало две основе етапе у одржавању обичаја. У периоду између два светска рата, посебно тридесетих година, када Дрежница припада Савској бановини и Краљевини Југославији, па до око почетка шездесетих година, када припада федералној Хрватској и новој, социјалистичкој Југославији, мачкаре су, у време Поклада, одржаване на један начин. Њих одликују: прерушавање, односно симболичка промена полних улога (маскирање момака у девојке), прибављање информација о девојкама и почетак увођења момака у ред ожењених људи, сеоска и родовска егзогамија (осим Брзеног), музика, песма, шала, опуштена атмосфера. Одржавање мачкара је после Другог светског рата забрањивано. Због знатног губитка становништва у рату, одлива становништва после рата и у колонизацији и накнадним миграцијама, те због забране одржавања, мачкаре су средином шездесетих година преузела деца, дечаци и девојчице школског узраста, који су маскирани ишли кроз села и добијали дарове. Од тада се повремено одржавају. То је друга етапа у њиховом развоју. Главна сметња њиховом одржавању је општа депопулација и помањкање деце. У Дрежници је школске 2018/19. године било 11 ђака.

Кључне речи: усмени извори (грађа), мачкаре, Дрежница, Бајмок, Краљевина Југославија, социјалистичка Југославија

\section{1. Увод}

У овом прилогу сакупљено је петнаест усмених (десет основних и пет помоћних) и један писани исказ о мачкарама из Дрежнице. ${ }^{1}$

\footnotetext{
${ }^{1}$ Писани исказ преузет је из рукописа Душана Р. Косановића о животу у Кракару, који је настао на предлог и подстицај писца ових редова (в. Kosanović 2003).
} 
Грађа је сакупљана у периоду од 2000. до 2013. године у Дрежници и Бајмоку, где је једна трећина дрежничког становништва колонизована непосредно после Другог светског рата. Највећим делом сведочи о мачкарама извођеним тридесетих година прошлог века, у време када је Дрежница припадала Краљевини Југославији и њеној Савској бановини. 0 мачкарама сведоче они који су у њима учествовали и они који су их као домаћини и становници села (у које су долазили) дочекивали и испраћали. Тако су се на списку саговорника, сећајући се детињства, младости и зрелог доба, нашли и мушкарци и жене. У једном случају реч је о младићу и девојци из истог села, Косановићи, који су касније постали супружници. Грађа сведочи и о мачкарама после Другог светског рата, када је Дрежница била део федералне Хрватске у социјалистичкој Југославији и у периоду после 1991. године, од када је у саставу самосталне Републике Хрватске. Мањи део грађе односи се на мачкаре у Бајмоку. Она сведочи о покушају Дрежничана да организују мачкаре у свом новом завичају. Свим саговорницима постављено је исто питање: „Знате ли нешто о мачкарама?“ Потпитања су у тексту стављена у заграду и означена италиком. Уз податке о саговорницима, у заградама је назначено место и време кад су вођени интервјуи.

\section{2. Грађа и коментари}

\section{1. Слободан Косановић}

Мачкаре су ишле иза водице, кад је поп са межњаром ${ }^{3}$ обилазио куће, прије Коризме, када почиње пост. ${ }^{4}$ Био сам 1939. и 1940. године, два пута у мачкарама. Иста партија оба пута: Косановић Слободан, свирач на цитрама ${ }^{5}$, Косановић Стојан, Косановић Сава, Косановић Никола, торбоноша, Ивошевић Душан Лацин, Ивошевић Живко Оичов, Ивошевић Стојан Годин и Ивошевић Никица Црни из Лисине, бисаге је носио. Нашли се у Косановићима, тамо се обукли... По мојем женску

\footnotetext{
${ }^{2}$ Слободан Косановић (р. 1921), Косановићи, Кракар (Бајмок, 14. јул 2000).

${ }^{3}$ Межњар, межнар - послужитељ у цркви, црквењак, звонар.

${ }^{4}$ Велики или Часни пост код православаца, за који католици користе реч 'Коризма', траје шест недеља, од Поклада (Чистог понедељка) до Цветне недеље. Употреба речи 'Коризма' упућује на близину католичког становништва. У том периоду благо се држи у штали, још се не гони на испашу, па се залихе хране знају потрошити. Тим поводом је у Дрежници настала једна пословица у стиху: „Коризма сву сламу догризла“ (Милија Ћупурдија, девојачко Радуловић (р. 1933), Бајмок, 12. јун 2019). ${ }^{5}$ У Дрежници се у народном говору за усну хармонику каже цитре, музике, музичиие, фајерище.
} 
сукњу и на глави нешто од шпица да је провидно, то су нам цуре давале... Да нас не препознају. Еклане шпице ${ }^{6}$. Сава и Никола ожењени само. Четри Благајца7 и четри Косановића. Сви у рајтхознама ${ }^{8}$, штуцнама ${ }^{9}$, чарапама заврнутим... и ципеле и женска сукња. Са нашим цурама у Косановићима одиграли игру, коло и пјесма. Испробали се и кренимо. Прво у Пражиће навратили код Јове Вргана, Пере Пражића и Миладина, па у Шкипине, па Зрниће. ${ }^{10}$ Десетак кућа у Зрнићима, ништа нисмо добили. Сланине, гра, јаја сакупили. Велики сњег био. Миланко организује дјецу да нас са грудвама нападну. Ја из пиштоља два метка у вис опалио, све се разбјежало. Ја сам био најмлађи од мачкара. У повратку у Шкипине, па код Душана Симића да му продамо зараду. ${ }^{11}$ Частио јелом и вином. Запјевали, одиграли ми, код њега у кафани. Воркапа жандармеријски наредник улази. Већ јављено из Зрнића.

(Какав је то пиштољ био?)

Колт 6,35. ... Позвао ме ван и рекао: „Да ниси чији си, одлежао би ти мени 24 сата у затвору." Очев пиштољчић. Душан није купио сабираштину од нас. Идемо ми код мог Ђедана у Косановиће. ${ }^{12}$ Све покуповао од нас. Да нам више новаца него што вреди. То смо ми код њега потрошили у радњи. Већ смо 1937. били одељени. Вино, ракију, јести, код Ђедана добијемо, кад дођу мачкаре. Он почасти, да би тај касније дошао, кад треба платити.

(Јесте ли певали у мачкарама?)

Ова кућа добра господара

Неће пустит мачкара без дара.

Ај, ова кућа добра господара

Неће пустит мачкара без дара. ${ }^{13}$

\footnotetext{
${ }^{6}$ Шпице - чипке.

${ }^{7}$ Становници села Благај у Кракару имали су своје летње станове у Конацима и Лисини. Зато су у исказу станвници Лисине наведени као Благајци.

${ }^{8}$ Рајтхозне - јахаће панталоне.

${ }^{9}$ Штуцна - део чарапе од чланака ногу до средине листа, грло чарапе без стопала.

${ }^{10}$ Очигледно је да су мачкаре бирале краћи пут, нису ишли преко Радојчића него на Пражиће, па кроз Сеочане до Зрнића; становници Пражића и Шкипина имају презиме Маравић, а села Зрнићи - Зрнић. Иза њих су даље села Чорти (презиме Маравић), Николићи (презиме Маравић), Локва (презиме Радуловић и Таталовић) и Папежи (презиме Таталовић), која припадају Доњој Дрежниици, у које мачкаре нису залазиле. 11 Душан Маравић Симић је био привредник и трговац, компањон Милина Таталовића Пуђе. Били су власници пилане и трговине у Дрежници. Важили су за најимућније људе онога времена.

${ }^{12}$ Раде Косановић Ђедан, повратник из Америке и трговац мешовитом робом, чија је радња била у Косановићима, рођак најмлађег учесника мачкара, Слободана Косановића. 13 У речи 'пустит', као и код неких других израза, осећа се утицај књижевног језика, што је посебно питање. Видећемо у другим и другачијим примерима исте песме - и
} 
То се задње пева, у колу, пре одласка. ${ }^{14}$ „Крушке, јабуке, шљиве“, „Кукуњешће“, цуре у колу са нама. ${ }^{15}$ Цуре нас откривају, а ми се не дамо. И догодине исту маршруту правили. „Дођите нам и догодине“ - сви су нам говорили. Покојни Дујо Ивошевић Лацин је започињао песме, погинуо у партизанима на Модруши 1942. године. ${ }^{16}$ У имућније куће у селу се иде. Ђе неко има родбину или цуру - тамо се највише ишло. То је била и една врста загледачине. Стојан Косановић и Стојан Ивошевић 1916. годиште, најстарији је Сава Косановић 1907, а Никола Косановић Срића 1897, торбу је носио. Никола са шљаком ${ }^{17}$ у под туче, да се нешто донесе. Ми уђемо у собу, па кад се отпева: „Ова кућа...“ он са шљаком у под удара. ${ }^{18}$... Никица Ивошевић Пезић је доста добро свира на цитре. Он ме замени. Стојан Ивошевић Годе, подај му велики капут јер нема, а добро је пјевао, сиромах. Њесмо га ћели избацивати из друштва. Зимски капути кратки, уз рајтозне, маје, капа, шешир. Шпице испод капе. Отвореније цуре или мушкарци па ти задигне сукњу - зафрканције. Живко Ивошевић знао глас промјенити кад би пјевали, као да је женско. Тој било кочење од смија. Погинуо 1944. у Истри, а Дујо 1942. на Модруши, Стојан Ивошевић у пролетерима крајем 1943, после капитулације Италије, неђе у Жумберку... Шира кикља ${ }^{19}$ по рајтознама, дугачка на валде ${ }^{20}$ - материна кикља. Шпице доста велике, мога си ји под капут ставити. Округла кошара без ручи, за бабине се носила, покривала се са шпицама. Биљчићи су се метали на кољевку... Биљчић доле, миље горе. Највише коло у мачкарама се играло.

то је један од разлога што је наведена у још два наврата - употребљава се реч 'пуштити'. Осим тога, овде је дата певана верзија песме. У дрежничкој традицији, кад је реч о ојкану, постоји десетак начина на који се слогови разлажу и понављају у стиху и на који се понављају речи у стиху или цео стих. У овом случају видимо да се одмах отпевају оба стиха а затим се понављају.

${ }^{14}$ Мачкаре певају песму уз лагано, шетано коло са задршком или повратком, три корака у леву страну и један назад, „насуво“, „брез музике“.

${ }^{15}$ Реч је о бржим колима која су тада била популарна и која су играна уз музику: „Крушке, јабуке, шљиве / мене воли Иве“ и „Кукуњешће, куку да / свирај свирче бадава“.

16 После његове „саране“ поједини становници села Благај, на чијем гробљу је сахрањен, засадили су јелу на његовом гробу. Пре неколико година један од мештана је посекао ту јелу, сметала је нечему.

17 Шљака је штап који је при врху савијен, како би се носилац могао боље ослонити на њега. Носили су га старији или болесни људи. У неким суседним селима, као Горњем брињском крају, служили су и „за олење“, као знак престижа, што је забележено и у појединим дрежничким песмама.

18 У свакидашњем говору народа Дрежнице 'под' означава таваницу али и патос, доњи под, мада се у овој грађи углавном односи на таваницу.

${ }^{19}$ Кикља - платнена сукња, део ношње.

${ }^{20}$ Валда - фалта, бора, набор. 


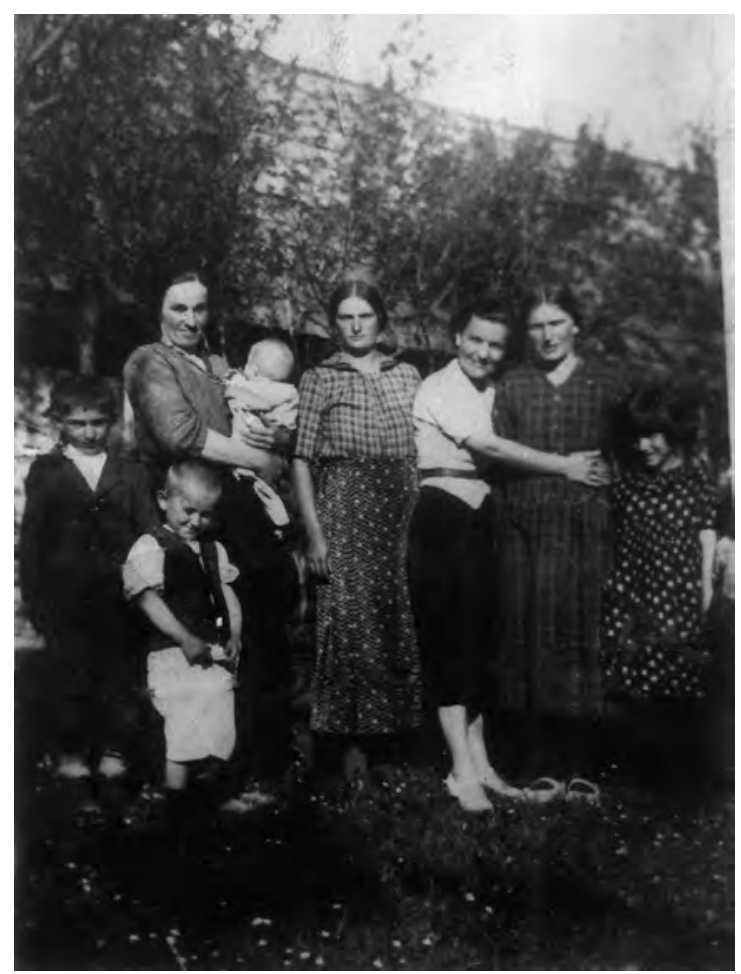

Сл. 1. Породице Косановић и Трбовић у Косановићима

\section{2. Марта М. Косановић ${ }^{21}$}

Мачкаре... Долазили су у Косановиће.

(Одакле су били?)

Што ја знам окле су. Есу конда носили штапе. Оно се преобуци свакако... Одиграј и ај даље. Отпјевај пјесму какву. Вавје дјецу страшили: „Одњеће те мачкаре“. Ђе су знали, ђе су цуре, туј су залазили.

(Је ли међу њима било девојака?)

Мушки су били, ма какве женске, враг. Није унда женске ки данаске свађе се нацртале и показивале ван се склањај ка змија кад бјежи.

(Шта су певали?)

Свакојаке пјесме, оне наше пјевали. Само нако играли уколо. Испревраћај робу на себи, да се дјеца плашу од њи. „Наздравље“, речу

${ }^{21}$ Марта М. Косановић (р. 1921), Косановићи, Кракар (Бајмок, 28. октобар 2012). 
акој чојк који вани и одлазе даље. Накити се. Објеси пешкире око врата. Низа се или упријеко. То би из њева села цуре њеве спремале. Код нас су други долазили, наши нијесу ишли.

\section{(Јесу ли добијали нешто?)}

Не би знала за дарове. Већином због цура ишли. Пјесме су пјевали. А ношње није било никве. Да прођу села и да виде какви су ђе обичаји. Нијесу улазили у-кућу. Неђе уђу и у-кућу, ђе су цуре. Отпјевају и оду. Види им се лице. Познало би се. Шљаке и штапе носили у руки. Играју с тијем. С пјесмом долази и одлази. Уној брајне брзо рат и све сам испуштила. 1941. Ђурђицу сам на глави на крст носила, Лазићи кумовали. ${ }^{22}$ Свитак на глави, па дјете сједи... и косцима воду и рану, све се носило на глави, едино дрва из шуме на уже и на леђа метнеш и носиш. Муке Исусове и јадан живот. Е, боже, свакога живота. Цуре би поиграле неђе с њима, неђе не би. Повришти и поскачи зеру ${ }^{23}$ и тако. Није било музике с њима. Насуво пјевају и играју. Још жене дражи дјецу ако нијесу добри - „одњећеј те мачкари“. Цуре вриште. Смиј. Бој се оће ји ко одати, да не би одњели дјецу. Дјеца се сакривај или бјеж, бој се да ће ји ћаћа или неко тужити мачкарама. Све на зафрканцију... Кроз село само пробакти ${ }^{24}$.

\section{(Јесу ли разговарали између себе?)}

Можда би у гостиони причали. На Месојеђе долазе... унда Коризма долази. Зими долазе. Поп по водици долазио. Њему је ваје требало метнути кој што има: пасуљ, сланине, сир. Поп и межњар иду, меће у торбу. Ун оно своје прокади и измоли и иде... У мушкој роби били. Неки широку материну сукњу обука, по свему озго, уноме... Само пешкири. Врак ји је гледа, бјежалој од њи ки од врага. Пјевај, све звони, пјевају цурама, зјај, скичи, вришти, цјела борба се чује.

\section{3. Душан Р. Косановић ${ }^{25}$}

„Mačkari: Iz detinjstva ostale su mi u pamćenju mačkari. Oni su išli po selima početkom februara meseca. Ulazili su samo u one kuće gde je bilo devojaka. Obično ih je bilo 15 do 20 momaka. Jedan od njih je imao torbu. On nije plesao već je bio kod šporeta i posmatrao. Uvek je zadnji izlazio. Domaćin je bio dužan da mu metne u torbu po komadić slanine ili šunjke. Bilo

\footnotetext{
${ }^{22}$ Ђурђица М. Косановић је најмлађа сестра казивачице, а Лазићи су надимак за једну породицу из Ћула (чији становници носе презиме Ивошевић) у Кракару.

${ }^{23}$ Зера - врло мало.

${ }^{24}$ Бактати - трескати, трупкати.

${ }^{25}$ Душан Р. Косановић (р. 1925), Косановићи, Кракар (Нови Београд, 15. новембар 2003).
} 
je kuća gde su lepo pevali i plesali a u torbi ništa nisu dobili. Bilo je mačkara da su se tako zamaskirali da ih devojke nisu mogle prepoznati“ (Kosanović 2003: 16).

\section{4. Раде Ћупурдија ${ }^{26}$}

Мачкаре... У Дрежници се ишло обавезно. Из свију села дођу дечки. Из Вукелића, Томића, Зрнића и Чорта долазили у Кракар... Преруше се у женско. Седам, осам мушкараца, пробуку кикље да су женске, мараме повежу, сисе направе... У све куће иду редом, да више добију. Нема ко неће дати. Сви смо били сиромашни али је свако дава. Исто као поп по водици кад је иша. Наручи камион и све прода што је добио. Музика.... коло, плес са цурама. „Кукуњешће“ је било најобичније. Кратке песме. Плес у двоје, па у четверо, два мушка и двије женске, брзо коло. Женске пршу по зраку... све брже и брже иде ${ }^{27}$, али кратко траје, јер морају сваку кућу обићи... Грле се, љубе цуре што гледају мачкаре, чапљу их. Цјели циркус. Вечера и цјело прело по завршетку се направи. ${ }^{28}$

\footnotetext{
${ }^{26}$ Раде Ћупурдија (р. 1926), Палице, Кракар (Бајмок, 8. август 2000). Становници Ћупића и Косановића у Кракару су имали летње станове на Палицама. Према сазнањима Милана Косановића Курије, писца књиге о презимену Косановићи у Дрежници, прва породица се стално населила у Палице у зиму 1894-95. године. То је била једна породица из Косановића. Те зиме је рано пао велики снег, људи нису могли да се врате у Косановиће и остали су на Палицама (Kosanović 2004: 26). Казивач о коме је реч је у народу познат као Раде са Палица, али се његов исказ о мачкарама односи на стари завичај, Кракар.

27 У овом случају очигледно је реч о познатом колу „опшај дири“, у коме најчешће учествују, наизменично ухваћени за руке (мушкарци) и рамена (жене), два мушкарца и две жене. Коло се постепено све више убрзава, тако да на крају жене, држећи се рукама мушкарцима за рамена, „пршу по зраку“.

28 Постоје још два краћа исказа о мачкарама у Кракару, у којима нема нових чињеница. Наводимо их јер је реч о другим селима, као потврду да су игране, и због језика. Први се односи на Ћупиће и Келиће у којима је саговорница рођена. „Мачкаре... Сами мушкарци ишли, марама, кикља, торбе. Добију месо, сланину, јаја, динаре, гра и друго. (Одакле су долазили?) Из Дрежнице долазили, од свакле. Продају то у Дрежници код Пуђе и поделе паре. Играју и пјевају“ (Даница Максимовић, девојачко Маравић (р. 1922), Келићи; разговор вођен у Бајмоку, 4. августа 2000). Други исказ се односи на Благај, у коме је саговорница рођена. Она се 1934. године удала и преселила у суседне Ћошане. „Сви се мушкарци пробуци у женско, пробуци кикље, накити их ручницима. Ко за сватове. Свако село своје мачкаре спреми. Едан носи торбу. Бациш им који динар у торбу. Дјеца иду за њима“ (Дарка Трбовић, девојачко Ивошевић (р. 1913), Благај; разговор вођен у Бајмоку, 9. августа 2000).
} 


\section{5. Душан Вукелић ${ }^{29}$}

Цитре сам почео свирати 1935-36. године, кад сам ишао у мачкаре. Састали се нас седам-осам дечака... Пражићи, Јагетићи, Трбовићи, ишли у Доњи крај... О Покладама. Певали... Згодни и високи су ишли у мачкаре... У бјелини иду мачкари. Идеш ђе те не познају. Онај са торбом пева и удара шљаком горе у под:

Ова кућа добра господара

Неће пуштит мачкара без дара.

Уちу у вежу ${ }^{30}$, певају... Почасти их. Пред кућом торбар пева, а остали до куће. На центру певају, на гувну. Торбар улази у сваку кућу, удара шљаком и пева. Скендер певао: „Што сеј Травник замаглио“. ${ }^{31}$ Певање, па коло без музике, шала, штипање. Са песмом се иде кроз село. Коло испред куће. Носач торбе улази у вежу и удара у под и пева: „Ова кућа...”. У врата или даске од патоса туче. Домаћица даје дар напољу да сви виде шта је дала, није сведно да ли да два јаја или сир. Сакупе добит. Па то продају: сланину, пршут, јаја, сир, новац. То се остави у селу па се после наврати по то. Продамо газди у кафани и за те паре пијемо. Неко остави себи и понесе кући храну, остало продају. Пије се и једе у кафани.

\section{6. Бранко Радуловић ${ }^{32}$}

Како не би зна... „Ели слободно?“, питају мачкаре. „Примаш ли мачкаре?“.

(Како су изгледале?)

Пешкири, маскирани. Сакривени плетивом ки буле. Шешир или капа.

(Ко је ишао у мачкаре?)

Првенствено мушки ишли у мачкаре. Женске чекају кући. Дочекују коло и мачкаре. Знају женске кој доша. Мачкаре пјевају:

\footnotetext{
${ }^{29}$ Душан Вукелић (р. 1922), Јагетићи (Бајмок, 11. август 2000).

${ }^{30}$ Вежа је предњи део куће, кухиња са отвореним огњиштем и отвором на крову, комином за проветравање, који се отвара комињачом, дугачким штапом. Поред огњишта се најчешће налази метални 'пријеклад' на ком се налажу дрва, а изнад огњишта су вериге (ланац) са једним или више котлова. У Благају се пре божићњег ручка во угонио у вежу, а укућани би га почастили са храном са трпезе и извели напоље.

${ }^{31}$ Илија Томић Скендер (р. 1909) из села Томићи. По том податку се види да је и он учествовао у мачкарама, осим, како је првобитно било казано, момака из Јагетића, Пражића и Трбовића. Сва поменута села су наблизо, једна су другима суседи.

32 Бранко Радуловић (р. 1927), Лукићи (Сеочани, 3. август 2012).
} 
Ова кућа добра господара

Јер непушта мачкара без дара.

Ако ниш не добију:

Ова кућа лоша господара

пуштила је мачкаре без дара.

А пјевали су и ову:

Игра баја и на баји торба

А у торби сланина и проја

Више вриједи сланина и проја

Него баја и бајина торба.

На прелу се договоре о мачкарама. Дарове што су добили продају трговцима па се почасте. Пију вино и пуше. Пиво из чаше...

(Је ли власт забрањивала мачкаре?)

Њесу мачкаре никада забрањивали. ${ }^{33}$ Сад нема ко ићи. ${ }^{34}$

\section{7. Бранка Б. Радуловић ${ }^{35}$}

Знам... Дјеца су наставила ићи у мачкаре. Плеши по кући и лупај са штаповима. Без прекида ишле мачкаре. Мјешано, до 15-16 година дјеца. Сад не иду мачкаре. Нема дјеце. „Примате ли мачкаре?“. Куцају штапима. Иду у круг. Пјевају: „Ова кућа...“. Јаја, месо, новци. Бјеле плате, завеса преко главе и пешкир. Први пут сам ишла у мачкаре 1963-4. године. Нису биле скоро мачкаре. Сад дођу Дрежничари из града и иду по кућама. Дођу за зимске празнике, па иду и у мачкаре. Задњи пут су ишли пре 4-5 година. Цуре и дечки заједно. Иду из Лукића у Босниће и Шкипине и Маравић Драгу. У сумрак кренемо, најпре Лукиће обиђемо, па у Шкипине, да се завара окле су. И од укућана се скривало то, да не знају да ће ићи мачкаре. Дарове подјелимо између себе.

(Колико ђака има у Дрежници?)

У Дрежници је 1985. било око 80 ученика, 2012. око 18 ученика. ${ }^{36}$

\footnotetext{
33 Казивач мисли на време после Другог светског рата, када су власти, иначе, забрањивале одржавање појединих обичаја.

${ }^{34}$ После Другог светског рата у мачкаре су почеле ићи деца школског узраста. У тренутку давања исказа, 2012. године, у Дрежници је било око осамнаест ђака школског узраста, а данас их има десетак. Зато он каже да нема ко ићи у мачкаре.

${ }^{35}$ Бранка Б. Радуловић (р. 1959), Лукићи (Сеочани, 3. август 2012).

${ }^{36}$ За разлику од Дрежнице, где су одрасле мачкаре замењене дечјим, у српским селима Баније, као на пример у Бојни, која у пет заселака има 132 куће, а припада општини Глина, на Покладе су ишле и дечје и одрасле мачкаре. У мачкаре одраслих,
} 


\section{8. Милица Маравић ${ }^{37}$}

Да, да... Некав је стари иша пред дјецом двије-три године. Унда су забранили. Тој било на Покладе... Мачкаре... у Зрнићима. Омладина за њим иде. Чутуре су имали, шили гаће од плата, торбе носили. Главни је носио штап. Кад добију дар, још отпјевају пјесму.

(Јесу ли иуре ишле у мачкаре?)

Нису цуре ишле у мачкаре.

\section{9. Тодор Радуловић ${ }^{38}$}

Сјећам се мачкара. У њима су ишли брат Нина, 1924. годиште, Душан Лајзин око 1925. годиште, Мића и Марко. Мића је у пролетерима погинуо а Марко на Жњидавцу. Они су око 1924. годиште били... Радуловић Ђуро Пјевац, Мане Радуловић Паун, Душан Радуловић Американичин, Таталовић Петар, Маравић Ђуро из Кубота. Ишли су од куће до куће, замаскирани. Код нас су већ дошли замаскирани. То је било пред рат, 1939. године. Ја сам иша у школу. Сњега је било кад су дошли. Ја сам био у другом разреду кад су мачкаре ишле. Капа, шешир, нешто провидно на лицу. Пјевају и вичу: „Ово је добар домаћин.“ Давао је отац дарове. Цитре и тамбурице су имали. Играју пред кућом. Један је уша у кућу. Најстарији улази Ђуро Маравић. Ђуро држи штап и куцка да се чује. Он је носио торбу са собом. У врата куца и назива добар дан. Тата излази и пожели им добар дан. Играју коло. Лаче и сукња-хаљина на себи. По засеоцима Брезног ишли, за даље не знам. Дјеца то гледају. Било интересантно. Рану вероватно поделе. Било је сиротиње.

(Јесу ли завршили у кафани?)

Није било кафана у Брезном. Ђуро је главни, он води и носи торбу и штап. Само он има штап, а торбе имају и други, вежене торбе што

којих је било две, три групе, ишло је у свакој око пет момака старости од 17 до 20 година. Они се преруше, нареде се као сватови: деда, баба, млада, младожења, девер. „Догоди се да иду у друго село, па се као тобош ексцес догоди“... „Све су дјеца исто радила - дјечје мачкаре. Све су дјечаци, њих четири-пет. Женских нема у мачкарама. Дјед, баба, млада и младожења. Иду сиромашнија дјеца, од 5 до 12 година. Њих нико није дира. Више су дјеца добијала нег велики“... „Задњи пут сам 1969. ишао. Узели се 1970. а 1971. се преселили у Загреб“. У Загребу су живели до рата, 1991. године, кад су се вратили у Бојну, где су били до 1995. године, када су у Олуји дошли у Бајмок (саговорници: Драган Ћеран (р. 1949) и Нада, девојачки Грмуша (р. 1952), разговор вођен у Бајмоку, 17. фебруара 2013).

${ }^{37}$ Милица Маравић, девојачко Зрнић (р. 1942), Зрнићи (Бајмок, 2. фебруар 2013).

38 Тодор Радуловић (1932), Брезно (Бајмок, 26. фебруар 2013). 
су жене правиле. Дечки су то били. Едан је има пешкир преко рамена. Ђуро је био ожењен, за друге не знам, Ђуро из Кубота, око 1924. годиште. Убили га усташе.

\section{(Је ли било посматрача са стране?)}

Није било народа са стране. Био је ту и Ђуро Боснић из Ардуна. Нас је у-кући било осморо деце и деда и баба и родитељи - дванаест чланова, у школи смо становали, у посебној кући. Имали смо десетак крава, волове, коње. Штерња ${ }^{39}$ је била за све код нас. Дјеца су била у школи, па су гледала мачкаре. ${ }^{40}$

\subsection{0. Михајло Маравић ${ }^{41}$}

Њесам иша у мачкаре у Пражићима. У јануару или фебруару 1947. године нас десетак момака је ишло у мачкаре у Бајмоку: ја, Ђуро Арбез, Милин Костин, Дуја Ћошан. ${ }^{42}$ Ишли смо са Арбезовим колима. Некој свира цитре. Ишли смо тамо ђе су цуре, ђе се удаје... Код Кове Газдице су биле двије цуре. ${ }^{43}$ Све момци били, са торбом. У Бајмоку нам милиција није дозволила да даље идемо. Отишли смо у Алекса Шантић, ђе нас људи њесу прихватили, бјежали испред нас, па смо завршили у кафани пјевајући. Марама преко лица, женске кикље по лачама. Појели смо сланину и месо што смо зарадили... нешто и попили.

\footnotetext{
39 'Штерња', у неким другим крајевима 'бистијерна' и слично, јесте бунар с изворском водом или резервоар са кишницом.

40 У Брезном „мачкаре шљакама ударају у под док играју у колу, пјевају пјесму и вришту. Пјевају: „Ова кућа...“ Добију сланине и новаца (Никола Боца (р. 1927), Брезно, разговор вођен у Бајмоку, 8. августа 2000).

${ }^{41}$ Михајло Маравић (р. 1925), Бајмок (Бајмок, 18. јул 2000).

${ }^{42}$ Казивач је навео учеснике у складу с дрежничком традицијом означавања људи у свакидашњем говору, према 'шпиц наметима' (надимцима). Реч је о Михајлу Маравићу Мићи Пражићу, родом из Пражића, Ђури Радуловићу, тј. Ђури Арбезу родом из Радловића, Мили Радуловићу Милину Костину, родом из Брезног и Душану Трбовићу Дуји Ћошану, родом из Ћошана у Кракару. Овакав састав учесника је био готово незамислив у старом крају, Дрежници, јер потичу из разних и удаљених крајева Дрежнице. По колонизацији у Бајмок после Другог светског рата, те разлике су изгубиле на значају. Учесници су при насељавању другачије распоређени, а и систем насеља је другачији.

${ }^{43}$ Казивач има у виду породицу Марка Јове Маравића, која је из Маравић Драге (из Мараса) насељена у Бајмок, а имала је кућу и вински подрум у Франкопанској бр. 6 (Ћупурдија 2010: 188).
} 


\subsection{1. Раде Ћупурдија ${ }^{44}$}

Симо Томић је главни организатор за мачкаре био у Бајмоку. Знао је пјевати и играти. Забраниле су то власти. То је 1946. или 1947. било. Унда су им наши забранили. Да је то срамота од Буњеваца и Мађара у Бајмоку... ${ }^{45}$

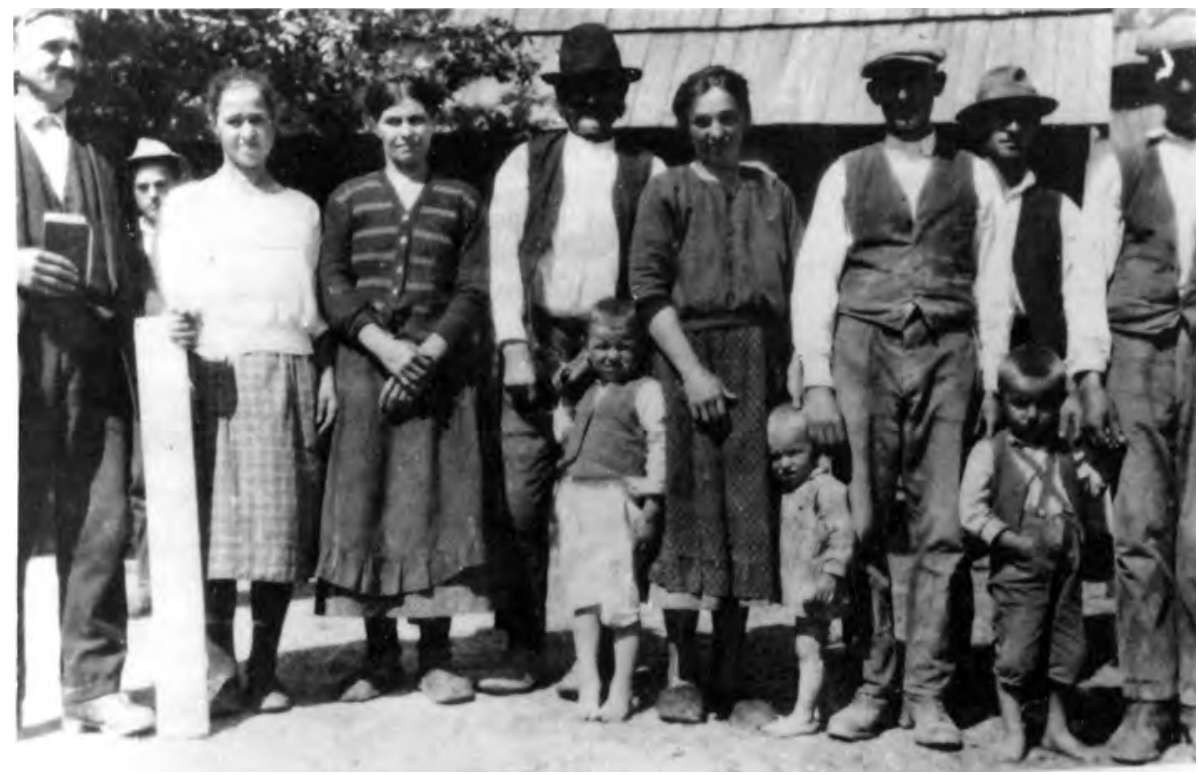

Сл. 2. Становници Косановића

\footnotetext{
${ }^{44}$ Раде Ћупурдија (р. 1926), Бајмок (Бајмок, 8. август 2000).

45 Очигледно је да, као нови становници Бајмока, Дрежничани још нису знали да и староседелачко буњевачко и мађарско становништво познаје сличан обичај, вашанге. Код Буњеваца, машкара је „maskirana osoba“ („Ajde, friško, dico, evo iđu nam maškare 'običaj o pokladama і о Božiću'“), као и вашанга - „maskirano lice (čestitari o pokladama i drugim praznicima, kada je to običaj“ (Реić 2018). На салашима у околини Суботице обичај се у време свињокоља изводио још до почетка осме деценије прошлог века (када су вршена истраживања). За ту прилику се код буњевачког становништва користи израз „намашкараје се“. „Намажу се чађу, обуку се у сукње, направе се машкаре. Женске се обуку у мушка одела. Мушкарци се оправе као да су Цигани. Шибају се батинама, разгаламе се и руше ствари око себе. Онда уђу унутра на вечеру“ (Ћупурдија 1993: 118, 126).
} 


\section{3. Историјски, друштвени и регионални контекст}

Из изложене грађе се види да су мачкаре обилазиле многа дрежничка села, било да су их примали, било да су их из својих села отпремали у друга села. Поменуте су највеће групе дрежничких села, Кракар, који је имао 7, Брезно, у коме је било 10 и Сеочани, који су имали 11 заселака (Maravić 1982: 12-13). То значи да су мачкаре биле општа и веома прихваћена појава у Дрежници. Било је уобичајено да не иду у своје село, него да обилазе друга села. На одређен начин то је у вези са егзогамијом. Ако би након проласка мачкара дошло до упознавања девојке и склапања брака, девојка би била из другог села, из другог „рода“ у коме углавном сви становници носе исто презиме. Од овога унеколико одступа грађа из Брезног, у коме мачкаре обилазе десетак својих заселака. У вези с тим треба имати у виду неколико чињеница. Прво, Брезно је, у односу на друга дрежничка села, насељено релативно касно, у 19. веку, из више дрежничких села: Радуловићи из Белаца, код центра Дрежнице, Радуловићи из Радловића, Маравићи из Николића, Куботи из Селишта, Мараси из Маравић Драге, Кулаши из Шекића, Боснићи из Боснића и Вукелићи из Вукелића, са једном српском породицом из Кунића (Боце) и са неколико хрватских породица из Сабљачке Драге и Модруша (Рендулићи, Гашпаровићи, Сабљаци, Антончићи) (Maravić 1982: 13, 30-31). Самим тим, традиција коју су они донели већ је једном била ишчупана из корена. Ту је, од свих дрежничких села, највидљивији директан додир српског и хрватског становништва. Друго, од свих дрежничких села Брезно је најближе Огулину. Могуће је да је близина градског насеља утицала на начин одвијања мачкара. Треће, пред сам рат учитељ Матија Фербежар, хрватске националности, у брезнарској школи је једном организовао ђаке, дечаке и девојчице, да направе мачкаре. ${ }^{46}$ А из искуства је познато да када неки обичај преузму деца или Роми, то је поуздан знак његовог губљења или, у бољем случају, новог почетка. Све су то показатељи либералнијег односа према мачкарама.

\footnotetext{
46 „У ходнику код школе су се пресвлачили. Било их је десетак. Доњели су прње од куће и пресвлачили се. Дечки су се маскирали да се не види лице. Цурице су панталонице имале, дечки сукњице и хаљине. Дечкићи су шешириће имали а цурице капице неке на глави. Није се знало ко је ко. ... Не знам есу даље ишли куда. То сам едном видио. Нису имали штап и торбу. Мати моја им однела јаја, шећер у коцкама и тако. Био је учитељ с њима. Он је то ваљда организова, Матија Фербежар. С њим су биле две сестре. У школи су имали стан. Селио сам га у (Мусулински) Поток кад је заратило. Дјеца га пјешке селила. Тамој има колегу, Хрват је био, па је иша код колеге. После се никад није вратио. Унда је тако и заратило. Стринина сестра Маца тамо живила. Навече се вратили кући у Брезно“ (Тодор Радуловић, разговор вођен у Бајмоку 26. фебруара 2013).
} 
Мачкаре понекад предводи један старији, ожењен мушкарац, а понекад двојица ожењених мушкараца. Они су проверени: знају с девојкама и женама. Сада је ред да поуче момке како да дођу до таквих искустава. Ако одлазе у имућније куће, то је зато да буду сигурни да ће за своју посету добити нешто заузврат; ако одлазе тамо где имају рода, то је зато да их неко може прихватити и обавестити о ситуацији у селу, па и међу девојкама. Али, углавном иду тамо где има девојака. Као маскирани, желе да виде а да не буду виђени, да што више сазнају а да не буду откривени, иду у „загледачину“ - то је основни смисао њихове посете. Преобучени уженску одећу, симболички су заменили полне улоге. Уз песму, коло, музику и шалу, то доприноси веселој атмосфери у којој се лакше може доћи до жељених података о девојкама и породицама из којих потичу. Дарове, храну и новце, које су добили заузврат, на крају потроше и почасте се. Реч је, дакле, о једном друштвено прихватљивом и уобичајеном начину на који младићи стичу обавештења о девојкама и њиховим породицама и о једној врсти забаве. Та пракса је постојала све до Другог светског рата и једно кратко време после тога. А онда су постепено, што због забрана одржавања, што због депопулације Дрежнице, обичај преузела деца, дечаци и девојчице. То се добро види у селу Лукићи, где се деца средином шездесетих година појављују као носиоци мачкара. Мачкаре се појављују и самим крајем осамдесетих година, пред рат. После тога се спорадично изводе у Дрежници. Сада има десетак деце школског узраста и нема ко да иде у мачкаре.

Највећи удар претрпело је становништво Дрежнице у Другом светском рату, када су, од око 6000 становника (Ivošević, Sobolevski 1982: 49), живот изгубила 864 лица (Banda 1982: 841), међу којима су и многи учесници мачкара. Они нису имали прилику да наставе са мачкарама, упознају девојке, ступе у брак и бољи живот. Велики одлив становништва Дрежнице догодио се и у периоду од 1945. до 1948. године, када је колонизовано у Бајмок 300 породица са око 1704 појединца (Ћупурдија 2010: 241, 243). Тако је становништво Дрежнице по првом попису проведеном после Другог светског рата било више него преполовљено. Дрежница је 1948. године имала 2661, 1953. године 2601, 1961. године 2355 и 1971. године 1465 становника (Gal 1972: 51). „Migracija stanovništva je naročito intenzivna posljednjih desetak godina. To je odraz privredne nerazvijenosti kraja i neimanja izgrađenosti osnovnih objekata infrastrukture (asfaltne ceste, vodovod, zdravstvene stanice). Investicionih ulaganja u privredu Drežnice gotovo i nije bilo“ (Sobolevski 1971). Иако је Дрежница касније добила асфалтне путеве, телефонску мрежу, водовод, амбуланту и друго, број становника се стално смањивао, да би по последњем попису становништва проведеном 2011. године, имала 516 становника. То су друштвени услови у којима су се угасиле мачкаре одраслих и настале дечије мачкаре, које се, такође, гасе. 


\section{4. Закључак}

У периоду између два светска рата мачкаре су у дрежничким селима биле општа и прихваћена појава. Оне су израз патријархалних друштвених односа који владају у локалној заједници и капиталистичких односа у друштву Краљевине Југославије. Основни смисао мачкара је да, предвођене ожењеним мушкарцима, омогуће момцима да почну загледати девојке. Они, прерушени у девојке или жене, симболички замењујући полне улоге, користе предности патријархалног система, да виде девојке а да не буду виђени и да изблиза упознају девојке и породице у којима живе. Све се одвија у веселој атмосфери, уз песму и музику, што доприноси опуштању и искључивању из свакидашњих обавеза. То је активност која унеколико личи на проводаџисање, можда је прецизније рећи да она може претходити проводаџисању, јер директног упознавања младића и девојака ипак нема. У склапању ових „познанстава“ одабрана су она села у којима девојке младићима нису род, што значи да се владају према принципу сеоске и родовске егзогамије. Од тог принципа се унеколико одступа у Брезном, где мачкаре обилазе властите засеоке. То може бити зато што је реч о млађем и унеколико етнички мешовитом насељу које је настајало током 19. века, чији становници су различитог регионалног порекла, и што се налази у близини градског насеља, Огулина. Такво одржавање мачкара у Дрежници трајало је још једно краће време после Другог светског рата. Промена основне друштвене матрице, чији су темељи положени у Другом светском рату, довела је до тога да мачкаре постепено преузму деца. У темељима тог процеса налазе се и: губитак становништва у току рата, колонизација у Војводину и накнадне миграције становништва у друге крајеве, забрана одржавања мачкара и друго. Прве мачкаре које су одржавала деца регистроване су у Лукићима, око средине шездесетих година прошлог века. Од тада се повремено одржавају, због опште депопулације и посебно помањкања деце. У Дрежници је школске 2018/19. године било 11 ђака.

\section{Библиографија}

Banda, Milica (1982). Ljudski gubici na području općine Drežnica od 1941. do 1945. godine. У: Đuro Zatezalo (yp.) Partizanska Drežnica. Karlovac: Historijski arhiv u Karlovcu, Zbornik 12, 841-896.

Gal, Ivan (1972). Stanovništvo i zaposlenost. У: Ivo Žuvela (yp.) Ekonomsko-društveni razvoj Partizanske Drežnice 1972-2000. Rijeka: Ekonomski institut, Samostalna organizacija udruženog rada u sastavu Ekonomskog fakulteta Rijeka, 50-69. 
Ivošević, Lako i Sobolevski Mihael (1982). Drežnica između dva svjetska rata. У: Đuro Zatezalo (yp.) Partizanska Drežnica. Karlovac: Historijski arhiv u Karlovcu, Zbornik 12, 49-67.

Kosanović, Dušan R. (2003). Život u Krakaru. Beograd: Rukopis, 38 strana.

Kosanović, Milan M. (2004). Kosanovići poreklom iz Drežnice. Beograd: Autorsko izdanje.

Maravić, Manojlo (1982). Iz prošlosti Drežnice do 1918. godine. У: Đuro Zatezalo (yp.) Partizanska Drežnica. Karlovac: Historijski arhiv u Karlovcu, Zbornik 12, 11-48.

Peić, Marko i dr. (2018). Rečnik bačkih Bunjevaca: iliti Ričnik bački Bunjevaca. Novi Sad: Matica srpska: Nacionalni savet bunjevačke nacionalne manjine.

Sobolevski, Mihael (1971). Partizanska Drežnica. Ogulin: Zavičajni muzej Ogulin.

Ћупурдија, Бранко (1993). Суботица и околина. Нови Сад: Прометеј.

Ћупурдија, Бранко (2010). Породища колониста у Бајмоку 1945-1948. Београд:

Српски генеалошки центар.

\section{Саговорници}

Из Бајмока: Никола Боца (1927), Брезно; Душан Вукелић (1922), Јагетићи; Марта М. Косановић, рођ. Косановић (1921), Косановићи; Слободан Косановић (1921), Косановићи; Даница Максимовић, рођ. Маравић (1922), Келићи; Милица Маравић, рођ. Зрнић (1942), Зрнићи; Михајло Маравић (1925), Пражићи; Тодор Радуловић (1932), Брезно; Дарка Трбовић, рођ. Ивошевић (1913), Благај; Драган Ћеран (1949), Бојна; Нада Ћеран, рођ. Грмуша (1952), Бојна; Милија Ћупурдија, рођ. Радуловић (1933), Локва; Раде Ћупурдија (1926), Палице; из Дрежнице: Бранко Радуловић (1927), Лукићи, Бранка Б. Радуловић (1959), Лукићи. Из Београда: Спасо Косановић (1932), Косановићи.

\section{Извори илустрација}

Сл. 1. Породице Косановић и Трбовић у Косановићима (фото: Јелушић 1937). Власник фотографије: Спасо Косановић. На фотографији су: Никола Косановић (1928), Спасо (1932), Милија (рођ. Трбовић, 1907) и Ненад (1937); Даница Трбовић (рођ. Вукелић из Јагетића, удата у Ћошане); учитељица у Кракару Пава Косановић (рођ. Савић из Липика); Љуба Косановић (супруга Душана, мајка Слободана Косановића, учесника мачкара, сестра Даничина); и Љубина кћерка Мара.

Сл. 2. Становници Косановића (фото: Јелушић, 1938). Власник фотографије: Спасо Косановић. На фотографији су: Раде Косановић Ђедан, трговац; у гостима Мара Ивошевић из Благаја, рођ. Радојчић из Радојчића; Мара, Ђеданова жена, рођ. Косановић, тетка Маре Ивошевић; ћаће Мићо, отац Ђеданове жене Маре; Милија Косановић, рођ. Трбовић, из Трбовића; Слободан Косановић (учесник мачкара); Мићан Косановић (син ћаће Миће); Душан Косановић, отац Слободанов; деца: браћа Спасо и Ненад Косановић и, сасвим десно, Милан Косановић, Слободанов брат (потоњи књижевник). 


\title{
The Mačkare Carnival from Drežnica
}

\author{
Branko Ćupurdija
}

\section{Summary}

The subject of the paper is the mačkare carnival in the Serbian villages of Drežnica, situated at the border of Gorski Kotar, the Croatian Littoral and Lika. The research is based on fifteen oral and one written testimony, as well as on literature. The material was collected from 2000 to 2013 in Drežnica and Bajmok (where approximately one third of Drežnica inhabitants were relocated 1945-1948), and also in Belgrade during 2018. The research presents two basic stages in the preservation of the custom. From the period between World Wars, especially in the 1930s, when Drežnica belonged to the Sava Banovina and the Kingdom of Yugoslavia, until the beginning of the 1960s, when it belonged to Croatia, federal republic of the new, socialist Yugoslavia, mačkare were maintained in the same manner - during the Carnival. They are characterized by: symbolic change of gender roles through cross-dressing (boys disguise as girls), obtaining information about girls and the initiation of young men into the ranks of married people, rural and clan exogamy (except Brzen), music, singing, jokes, and relaxed atmosphere. Mačkare were banned after World War II. Due to significant loss of populace in the war, population outflow after the war, through colonization and subsequent migrations, and the performance ban, mačkare were taken over in the mid-1960s by school-age children, boys and girls, who went through villages disguised and received gifts. Since then, mačkare have been upheld occasionally. That would be the second stage in their development. The main obstacles to their perpetuation are general depopulation and lack of children (in the school year 2018-2019 there were 11 students in Drežnica).

Keywords: oral sources (material), mačkare, Drežnica, Bajmok, Kingdom of Yugoslavia, socialist Yugoslavia

Бранко Ћупурдија

Е-пошта: branko_cupurdija@vektor.net
Примљено: 1. 12. 2020.

Прихваћено: 29. 12. 2020. 